\title{
Speech Therapy for Neurological and Neurodegenerative Diseases in Adults
}

\author{
Raniya Naanai ${ }^{1,2 *}$ \\ 1Speech language pathologist, Al Noor Center for Physiotherapy \& Rehabilitation, Africa \\ ${ }^{2}$ Mirdif Center for Physiotherapy \& Rehabilitation, Dubai, United Arab Emirates
}

Submission: August 28, 2017; Published: August 30, 2017

*Corresponding author: Raniya Naanai, Speech language pathologist, Al Noor Center for Physiotherapy \& Rehabilitation, Casablanca, Morocco, Africa and Mirdif Center for Physiotherapy \& Rehabilitation, Dubai, United Arab Emirates, Middle East, Email: rania.nanaani@gmail.com

\section{Opinion}

Speech-language pathology is mainly for patients with neurological pathologies: traumatic cerebro-spinal, vascular most of the time, resulting in communication and swallowing disorders. The intervention of the speech therapist is part of the overall and multidisciplinary project of care, and on medical prescription.

The speech-language pathologist intervenes according to the case; directly into the patient's room if the patient's condition so requires and in his consulting office equipped with specific equipment and software.

The speech therapist exercises in a wide field of intervention

A. Assessment and assessment of communication and swallowing disorders

B. Implementation of rehabilitation programs with the help of adapted rehabilitation techniques

C. Individual and / or collective care
D. Education and association in case of need, the entourage and the relatives of the patient by giving them the appropriate advice to understand the brain injured person and the modes of communication to adopt when the use of speech is particularly difficult

1.2. Different techniques used

A. Exercises for the rehabilitation of speech disorders

B. Forms of non-verbal communication to supplement the functions reached (voice synthesis)

C. Actions of rehabilitation of disorders of higher functions: swallowing, attention, memory, behavior, neurovisual disorders

D. To achieve these objectives, the speech therapist has tools and techniques such as:

E. Computer aids, musical instruments, visual aids (photos), body mediation (eg, facial massages), language games

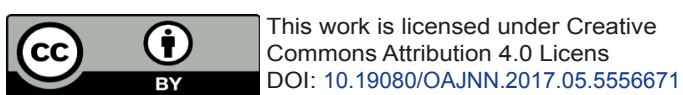

\begin{tabular}{l} 
Your next submission with Juniper Publishers \\
will reach you the below assets \\
- Quality Editorial service \\
- Swift Peer Review \\
- Reprints availability \\
- E-prints Service \\
- Manuscript Podcast for convenient understanding \\
- Global attainment for your research \\
- Manuscript accessibility in different formats \\
( Pdf, E-pub, Full Text, Audio) \\
- Unceasing customer service \\
Track the below URL for one-step submission \\
https://juniperpublishers.com/online-submission.php \\
\hline
\end{tabular}

